\title{
Power quality improvement using fuzzy logic-based compensation in a hybrid power system
}

\author{
Soumya Ranjan Das ${ }^{1}$, Debani Prasad Mishra ${ }^{2}$, Prakash Kumar Ray ${ }^{3}$, Surender Reddy Salkuti ${ }^{4}$, \\ Arun Kumar Sahoo 5 \\ 1,2,5 Department of Electrical Engineering, International Institute of Information Technology, Bhubaneswar, India \\ ${ }^{3}$ Department of Electrical Engineering, College of Engineering and Technology (CET), Bhubaneswar, India \\ ${ }^{4}$ Department of Railroad and Electrical Engineering, Woosong University, Daejeon, Republic of Korea
}

\section{Article Info}

Article history:

Received Sep 24, 2020

Revised Jan 19, 2021

Accepted Feb 9, 2021

\section{Keywords:}

Fuel cell

Fuzzy logic control

Microgrid

Power quality

Total harmonic distortion

\begin{abstract}
This paper is based on the improvement of power quality (PQ) using fuel cell and fuzzy based controller. By using the proposed controller, the quality of power in the grid system especially in micro grid connected with non- linear and unbalanced load is enhanced. The configuration of the system is combined with hybrid arrangement of photovoltaic ([PV) with wind energy conversion system (WECS), fuel cell (FC) including the compressed air energy storage system (CAES) where the power management is controlled by using the distributed power sharing technique. In this proposed system the distortions in voltage at point of common coupling (PCC) is decreased by using the FC which acts as compensator in hybrid system. Reference current is developed which depends on real and reactive power of the source connected to the compensator. Based on demand of power for nonlinear load, without using any external communication interfaces, the proposed control theory can change the modes of operation and can compensate the unbalance in the system which is caused due to single-phase micro sources and load changes. The complete productive design of the micro-sources and power electronic converters are presented in the paper. The operation and performance of the proposed controller used in microgrid is validated through simulation in MATLAB/Simulink environment.
\end{abstract}

This is an open access article under the CC BY-SA license.

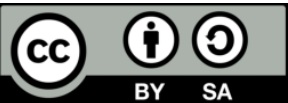

\section{Corresponding Author:}

Surender Reddy Salkuti

Department of Railroad and Electrical Engineering

Woosong University

17-2, Jayang-Dong, Dong-Gu, Daejeon - 34606, Republic of Korea

Email: surender@wsu.ac.kr

\section{INTRODUCTION}

In recent scenario modern power systems [1] faces different challenges like reduction in cost, losses in transmission system, heavy demand of power at load end and besides these challenges reliability condition is also an essential factor. To overcome these issues, presently the scientist and researchers are moving towards an alternative solution using the distributed generation (DG). This use of DG impacts an alternative to the development of the existing distribution networks [2], [3]. Nowadays less or medium DG systems, normally including power ratings from $1 \mathrm{KW}$ to $10 \mathrm{MW}$ connected at the load side are widely acceptable because of their better operating performance with high efficiency. At the present time several renewable source equipment like the PVs, FCs, along with micro-turbines are the best suitable DGs for power generation during peak hours in interior regions [4]. From a report it has been found during last few years, a significant development [5] in utilizing this renewable source equipment which is recognized, an appropriate 
result for distributed generation. Microgrids systems [6]-[8] constitute collections of loads and micro-sources. The microgrid must act single controlling unit to provide excellent value and consistent power that counters to system deviations. There exist a concerning issue on the synchronising $[9,10]$ and controlling the power quality disturbances because of large diffusion of DGs, together along linear and non-linear loads. To supply the preferred real and reactive power to the system connected in microgrid, the DGs are connected in parallel, besides the local signals are also utilised as feedback in controlling the converters. The distribution of power between the DGs can be realized by monitoring two parameters; one is the frequency while the other is the magnitude of the essential voltage. Introduction on fundamentals of microgrid followed by its configuration, protection scheme and management of power is presented in [11]-[13]. In [14] analysis of different current works on microgrid is discussed. Several policies of management of power with corresponding controlling techniques for a microgrid is projected in $[15,16]$. The performance of the microgrid during islanding and synchronisation is discussed in [17], [18]. The nonlinear loads (NL) connected in the microgrid generates harmonics [19], [20] which in turn produces losses in the system as well as reduce the efficiency level of the system. Existence of many power filters and FACTS controller, leads to compensate the harmonics and reduce the problems related to unbalance in three phase source and load conditions. To maintain an effective power management between the utility grid and microgrid, a series-shunt compensator is used and is discussed in [21]. Using this compensator, the power quality is enhanced between the two grid systems. The proposed method presented in this paper is validated using compensating device.

\section{SYSTEM CONFIGURATION}

Figure 1 represents the block configuration of the microgrid network. The microgrid consisting of different DG systems such as wind. FC, PV with energy storage system such as ultracapacitor (UC) and various linear and non-linear loads attached at point of common coupling. The distortion in the voltage at PCC is compensated using three control strategies namely droop control, STATCOM based control and fuzzy logic-based fuel cell compensation [22]. Figure 2 illustrates configuration structure of hybrid FC-DG system. The parameter of the different elements of the hybrid system is represented in Appendix [23].

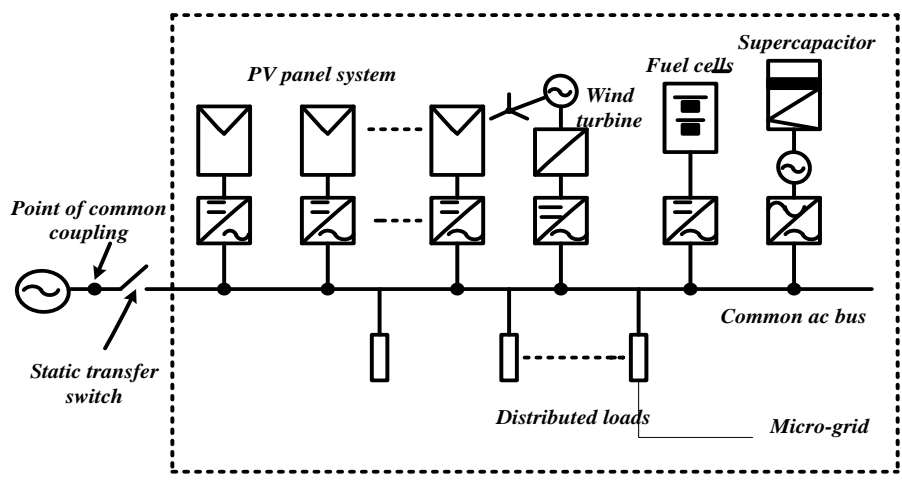

Figure 1. Block configuration of the microgrid network

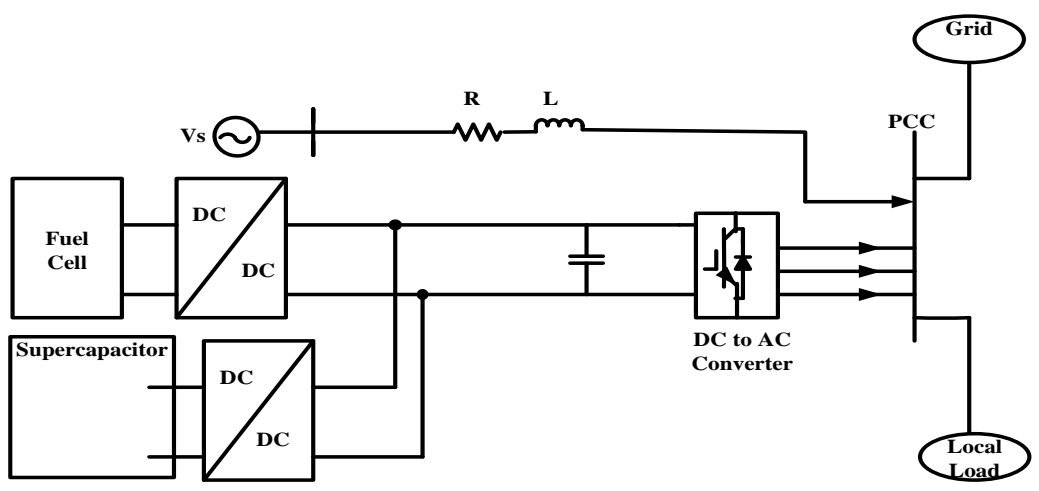

Figure 2. Configuration structure of hybrid FC- DG system 


\section{SYSTEM MODELING AND CONTROL STRATEGIES}

\subsection{Solid oxide fuel cell model}

Reference [24] proposes a developed and validated model based on the dynamic SOFC stack model. The (1) represents the voltage of the FC stack.

$$
\begin{aligned}
& V_{f c}=N_{0}\left(E_{0}+\frac{R T}{2 F} \ln \left(\left(\frac{P_{\mathrm{H}_{2} O_{2}}}{P_{\mathrm{H}_{2} O}}\right)^{0.5}\right)\right)-r I_{f 0} \\
& P_{\mathrm{H}_{2}}, P_{\mathrm{H}_{2} \mathrm{O}}, P_{\mathrm{O}_{2}} \text { are represented by the following (2), (3), and (4), } \\
& P_{\mathrm{H}_{2}}=-\frac{1}{t_{\mathrm{H}_{2}}}\left(P_{\mathrm{H}_{2}}+\frac{1}{K_{\mathrm{H}_{2}}}\left(q_{\mathrm{H}_{2}}^{\text {in }}-2 K_{r} I_{f c}\right)\right) \\
& P_{\mathrm{H}_{2} \mathrm{O}}=-\frac{1}{P_{\mathrm{H}_{2} \mathrm{O}}}\left(P_{\mathrm{H}_{2} \mathrm{O}}+\frac{2}{K_{\mathrm{H}_{2} \mathrm{O}}} K_{r} I_{f c}\right) \\
& P_{\mathrm{O}_{2}}=-\frac{1}{t_{O_{2}}}\left(P_{O_{2}}+\frac{1}{K_{O_{2}}}\left(q_{O_{2}}^{i n}-2 K_{r} I_{f c}\right)\right)
\end{aligned}
$$

$N_{0}$ is the number of FCs joined in series in the pack; $E_{0}$, normal no-load voltage; $R$, general gas constant $(\times 101.325 \mathrm{kPa} /(\mathrm{kmol} \cdot \mathrm{K})) ; T$ is the absolute temperature $(\mathrm{K}) ; i_{f 0}$, current in FC stack $(\mathrm{A}) ; F$ is Faraday's constant $(\mathrm{C} / \mathrm{kmol}) ; \mathrm{KH}_{2}, \mathrm{KH}_{2} \mathrm{O}$ and $\mathrm{KO}_{2}$ are the molar constants $(\mathrm{kmol} /(101.325 \mathrm{kPa} \cdot \mathrm{s}))$ of the hydrogen, water, and oxygen valves, respectively; $K_{r}$, modeling constant (kmol/(s.A)); $P_{\mathrm{H}_{2}}, P_{\mathrm{H}_{2} \mathrm{O}}$ and $P_{\mathrm{O}_{2}}$ are the partial pressure $(\times 101.325 \mathrm{kPa})$ of hydrogen, water and oxygen, respectively; $q_{\mathrm{H}_{2}}^{\text {in }}$ is the hydrogen input flow $(\mathrm{kmol} / \mathrm{s}) q_{\mathrm{O}_{2}}^{i n}$ is the oxygen input flow $(\mathrm{kmol} / \mathrm{s}) ; r$ is the FC internal resistance $(\Omega) ; t_{\mathrm{H}_{2}}, t_{\mathrm{O}_{2}}$ and $t_{\mathrm{H}_{2} \mathrm{O}}$ are the hydrogen, oxygen and water time constants (s), respectively [25]. The $K_{r}$ is evaluated from the behaviour among the rate of reactant hydrogen and the FC current, which is a constant value:

$$
q_{H_{2}}^{r}=\frac{N_{0} I}{2 F}=2 K_{r} I
$$

Where $q_{\mathrm{H}_{2}}^{r}$ represents the flow of hydrogen $(\mathrm{kmol} / \mathrm{s})$. The functional variable $U_{f}$, defined as the division of the total fuel and is presented as (6) [26],

$$
U_{f}=\frac{q_{H_{2}}^{\text {in }}-q_{H_{2}}^{\text {out }}}{q_{H_{2}}^{i n}}=\frac{q_{H_{2}}^{r}}{q_{H_{2}}^{i n}}
$$

Where, $q_{\mathrm{H}_{2}}^{\text {out }}$ is the hydrogen output flow $(\mathrm{kmol} / \mathrm{s})$. A huge application is required as it reduces the necessary fuel and flow of oxidant for a least fuel price. Furthermore, a basic prototype of reformer that produces hydrogen through methane is presented. The proposed model is having transfer function with second-order. The (7) represents the mathematical expression of the model [27].

$$
\frac{q_{H_{2}}}{q_{\text {methane }}}=\frac{C V}{\tau_{1} \tau_{2} s^{2}+\left(\tau_{1}+\tau_{2}\right) s+1}
$$

\subsection{DC/DC converter design}

It is highly required to raise the FC voltage and to raise quantity of cells for linking the FC with an external network. Function of this converter is to upgrade FC voltage, power control of FC and to maintain the voltage regulation. Figure 3 illustrates the model of DC/DC converter. The (8) and (9) represents two nonlinear state space averaged equations of the enhanced converter [28].

$$
\begin{aligned}
& \frac{d X_{1}}{d t}=\frac{1-d}{L} X_{2}+\frac{d}{L} U \\
& \frac{d X_{2}}{d t}=\frac{-(1-d)}{C} X_{1}-\frac{X_{2}}{R C}
\end{aligned}
$$


Where $d$ denotes duty cycle of the converter; $U$, input voltage; $X_{1}$, current in inductor; $X_{2}$, voltage across capacitor.

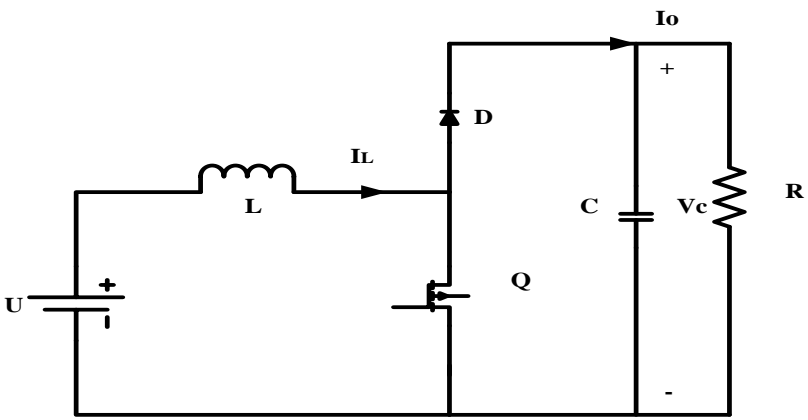

Figure 3. Boost dc/dc converter model

\subsection{DC/AC converter modeling}

A VSI is used in order to integrate various renewable energy sources between supply of the grid and the loads. Pulse width modulation (PWM) is extensively implemented in integrating a FC between the supply and load. For harmonic reduction, filters are allied in-between the converter and the power system, denoted by $L_{s}$ and $R_{s}$, respectively [29]. In Figure $4, V_{i a}, V_{i b}, V_{i c}$ and $i_{a}, i_{b}, i_{i c}$ are respectively AC three phase output voltage and output currents of VSI. While, $V_{s a}, V_{s b}, V_{s c}$ represents the grid bus voltage.

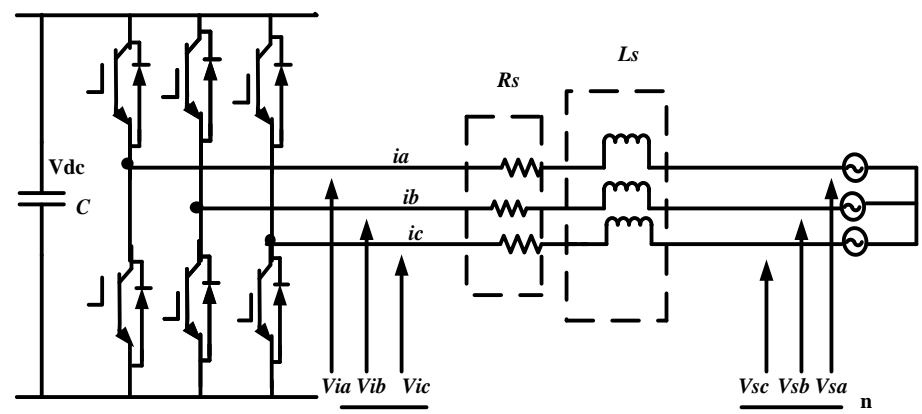

Figure 4. Three-phase DC/AC voltage source inverter

\subsection{Application of fuzzy logic control for fuel cell based copmensation}

Fuzzy logic control (FLC) is treated as one of the efficient approaches [23]-[25] in soft computing methods. FLC is derived from fuzzy set theory. FLC is very dynamic in dealing with complications like parameter variation, ambiguity and complexity in system design. For a conventional control system, the structure is based on mathematical design of the plant. To analyze any model, the system design or model with known parameters is needed. But in FLC the mathematical model is not required and can provide robust performance of the linear and non-linear control system with parameter variation. A fuzzy logic controller can be classified as fuzzification, knowledge base and defuzzification. Fuzzification is process of converting to linguistic variable from crisp value based on certain membership function. FC is utilised as an alternative for the typical PI controller. Block configuration of the FLC is equivalent to the scheme shown in Figure 5 where FLC are employed alternative to PI [30].

In this model the input to the FLC are the crisp values which are taken as error in voltage and its derivatives. And the outputs from the FLC are the crisp value which is considered as the reference voltages for the PWM generator. Tracking error and transient overshoots of PWM can be significantly decreased with the use of FLC. The control surface of the FLC can be built to represent suitable reactivity for individual operating point compared to the typical PI controller. The FLC is executed easily as an off-line pre-calculated with control surface of three-dimensional lookup table. Generally, the controlling parameter of a PI Controller is fixed. It has to be redesigned if there is variation in operation point of VSI [31]. 


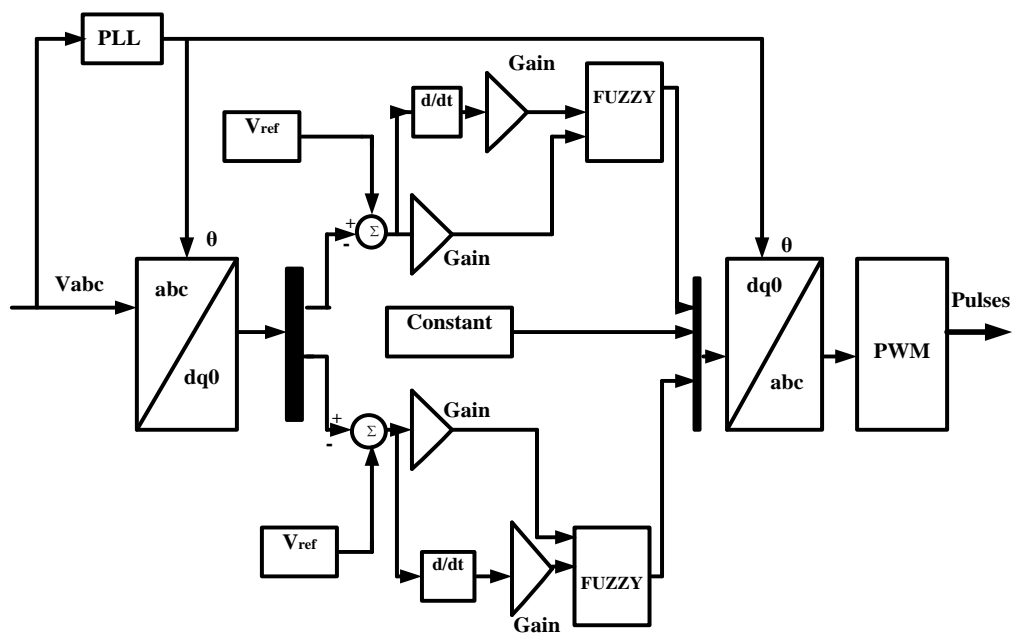

Figure 5. Block diagram for fuzzy controller (voltage regulator)

First FLC receives input crisp values as $V_{d}$ and $\Delta V_{d}$. Where, $V_{d}$ and $\Delta V_{d} \Delta \mathrm{V}_{d}$ are respectively the voltage error and its derivatives. Similarly, for the second controller $\mathrm{V}_{q}$ and $\Delta \mathrm{V}_{q}$ are considered as the output crisp values. Where, $\mathrm{V}_{q}$ and $\Delta \mathrm{V}_{q}$ are respectively the voltage error and its derivatives $\mathrm{V}_{\text {dref }}$ and $\mathrm{V}_{\text {qref }}$ are taken as voltage reference [32]. Figure 6 illustrates the triangular membership functions which behave triangular shaped by 50\%-fold over for an easy and advanced control tuning. Nine membership functions are induced in each variable. Where NL, N, NM, Z, PS, PM, P, PL are defined as membership functions. Figure illustrates an integrated coordinate system and can improved by means of normal boost for each variable, $\mathrm{G}_{e v d}$ for $\Delta \mathrm{V}_{d}$, $\mathrm{G}_{r v d}$ for $\Delta \mathrm{V}_{d}, \mathrm{G}_{e v q}$ for $\Delta \mathrm{V}_{d}$, and $\mathrm{G}_{e v q}$ for $\Delta \mathrm{V}_{q}$. The FLC with 81 rules is selected. The switching function is performed by FLC using the Mandani's implication and centroid method for de-fuzzification. The appropriate switching pattern for the converter is controlled by the triangular carrier modulation method. Finally, the gating patterns can be performed accurately [33], Fuzzy Rule shown in Table 1.

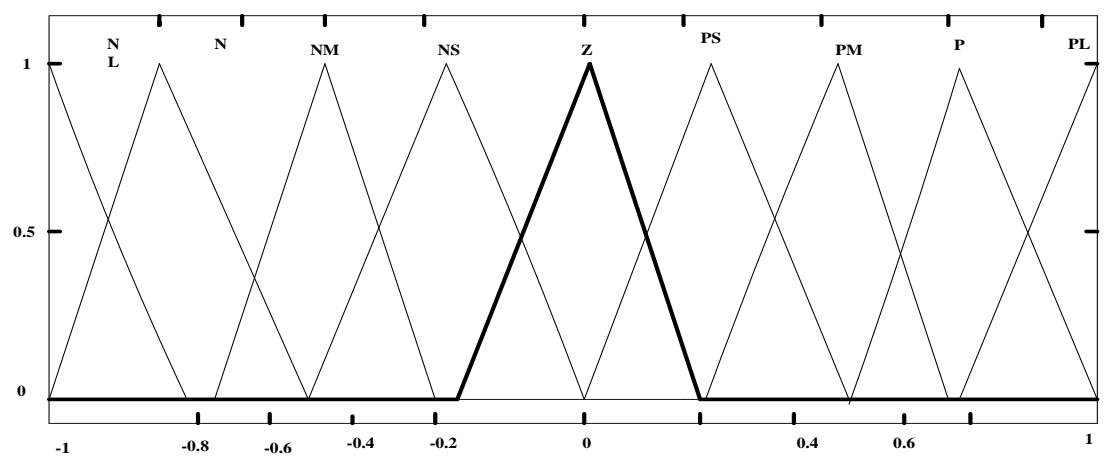

Figure 6. Triangular membership functions

Table 1. Fuzzy rule

\begin{tabular}{llllllllll}
\hline e & L & N & NM & NS & Z & PS & PM & P & PL \\
$\Delta \mathrm{e}$ & & & & & & & & & \\
\hline NL & NL & NL & NL & NL & NL & NL & N & N & NM \\
N & NL & NL & NL & NL & N & N & NM & NS & NS \\
NM & NL & NL & NL & N & N & N & NM & NS & NS \\
NS & NL & N & NM & NM & NM & NM & NS & NS & NS \\
Z & N & NM & NS & NS & Z & PS & PS & PM & P \\
PS & PS & PS & PS & PM & PM & PM & PM & P & PL \\
PM & PS & PS & PM & P & P & P & PL & PL & PL \\
P & PS & PS & PM & P & P & PL & PL & PL & PL \\
PL & PM & P & P & PL & PL & PL & PL & PL & PL \\
\hline
\end{tabular}




\section{SIMULATION RESULTS AND ANALYSIS}

To authenticate the proposed control strategy, a microgrid is simulated in MATLAB/Simulink. This microgrid is rated at $380 \mathrm{~V}$ (rms of phase-to-phase) and $50 \mathrm{~Hz}$ connected to non-linear load. Two DGs (PV and wind turbine) with FC and supercapacitors are connected in this hybrid system [34]. The carrier frequency of the interface inverters is $2 \mathrm{kHz}$. Harmonic compensation for the hybrid DG system under different scenarios of load is tested. The current profile of the hybrid system in the absence of the proposed controller under balanced nonlinear load is found to be $7.25 \%$ and $28.15 \%$ for source current and load current respectively. Simultaneously, the same system is tested under unbalanced nonlinear load, and the source current and load current profile shows around $10.15 \%$ and $35.16 \%$ respectively. The values are shown in Table 2. But after application of fuzzy controller, the current profile is observed to be improved. The principle behind the improvement is that FC power generation when surplus is being stored in the super capacitors. Then the stored power in super capacitor offers the required reactive power by the load in order to keep the voltage at PCC at constant value. System performance is operated for balanced and nonlinear load conditions and the corresponding source voltage $\left(V_{s}\right)$, source current $\left(i_{s}\right)$, load current $\left(i_{l}\right)$ and compensating current (ic) are presented in Figure 7. Their respective THD values are $1.80 \%$ and $19.18 \%$. It shows under balanced load the current is improved as compared to the system without controller. Figures $8 \mathrm{a}$ and $8 \mathrm{~b}$ shows the THD values of source and load currents. Now the performance of the system is analysed under unbalanced nonlinear load conditions. The corresponding source voltage $\left(V_{s}\right)$, source current $\left(i_{s}\right)$, load current $\left(i_{l}\right)$ and compensating current $\left(i_{c}\right)$ waveforms are shown in Figure 9. Their respective THD values are $3.90 \%$ and $19.84 \%$. The system performance is found satisfactory as compared to the proposed system without controller. The THD values are represented in Figures 10(a) and 10(b).

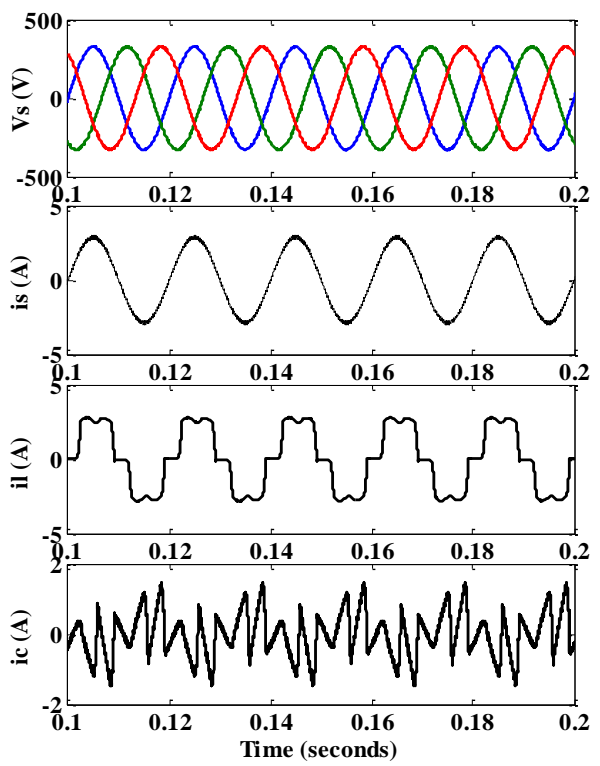

Figure 7. Performance of system balanced and nonlinear load

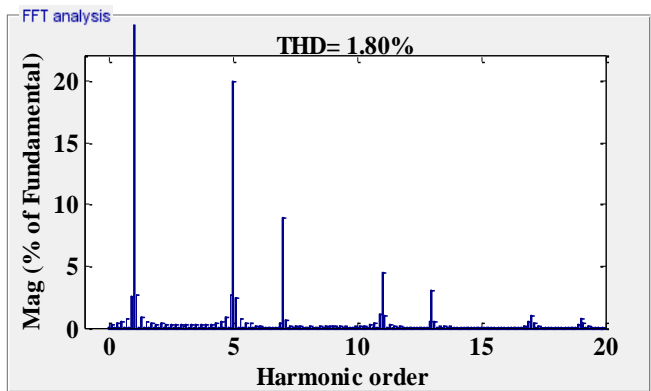

(a)

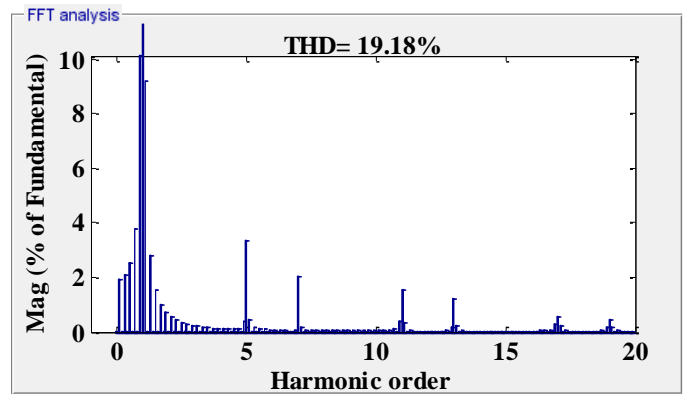

(b)

Figure 8. (a). Harmonic spectrum of source current, (b). Harmonic spectrum of load current 


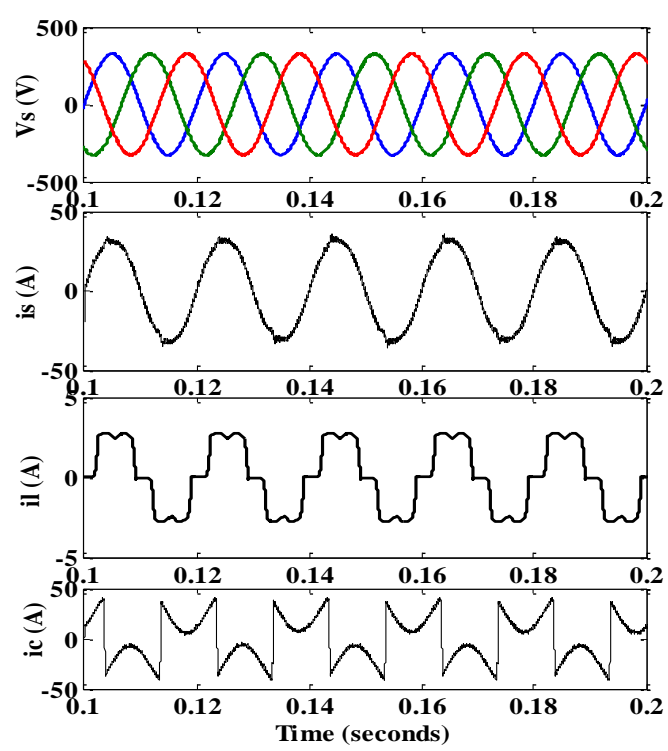

Figure 9. Performance of system under unbalanced and nonlinear load

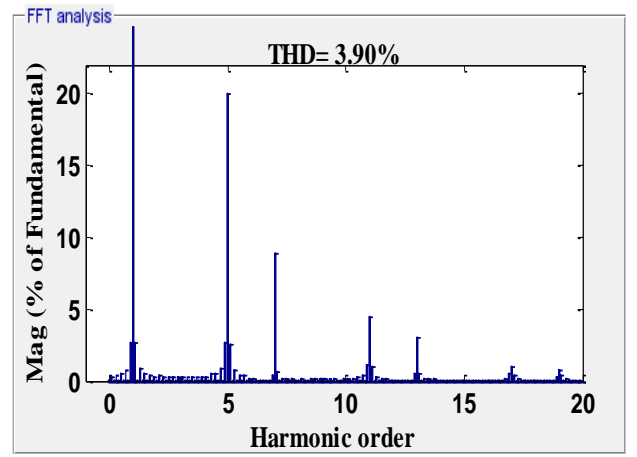

(a)

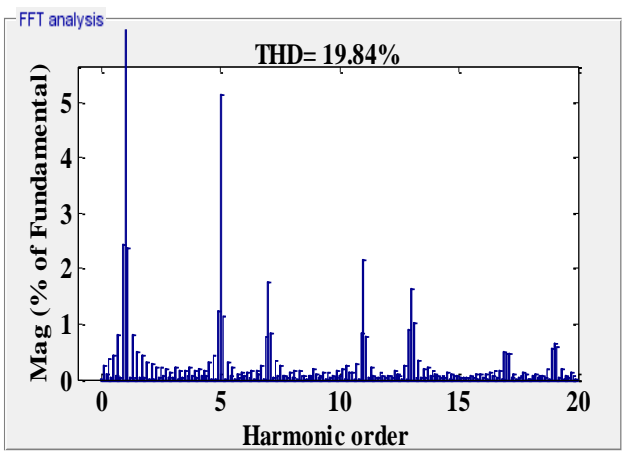

(b)

Figure 10. (a). Harmonic spectrum of source current, (b). Harmonic spectrum of load current

Table 2. THD analysis

\begin{tabular}{ccccc}
\hline \multirow{2}{*}{ Controller } & \multicolumn{2}{c}{$\begin{array}{c}\text { Balanced non-linear load conditions \% } \\
\text { THD analysis }\end{array}$} & Unbalanced non-linear load conditions \% THD \\
& $i_{s}$ & $i_{l}$ & $i_{s}$ & $i_{l}$ \\
\hline Without controller & 7.25 & 28.15 & 10.15 & 35.16 \\
With controller using FLC & 1.80 & 19.18 & 3.90 & 19.84 \\
\hline
\end{tabular}

\section{CONCLUSION}

In this paper, a hybrid power system based with PV, wind and FC has been proposed which is further integrated with inverter to eliminate the current harmonics in the source current. The compensating current is injected at PCC to reduce the level of harmonic content in the utility system. The proposed system employs FLC technique to perform fast with low complexity burden. FLC is operated under both balanced and unbalanced non-linear load. The results outcome reveals that the FLC is providing better performance under both the loads with minimum THD.

\section{APPENDIX}

The parameter of the different elements of the hybrid system is represented in Table 3.

Table 3. System parameters

$\begin{array}{llll}\text { Parameters } & \text { Value } & \text { Parameters } & \text { Value }\end{array}$




\begin{tabular}{|c|c|c|c|}
\hline Line voltage and frequency & $230 \mathrm{~V}, 50 \mathrm{~Hz}$ & Hysteresis band limit & $0.5 \mathrm{~A}$ \\
\hline Line and load inductance & $1 \mathrm{mH},(30,20,10) \mathrm{mH}$ & Sampling time & $2 \mathrm{e}-5$ seconds \\
\hline Load resistance & $(20,15$ and 10$) \Omega$ & $\begin{array}{l}\text { Switching frequency of boost } \\
\text { converter }\end{array}$ & $2 \mathrm{kHz}$ \\
\hline $\begin{array}{l}\text { Inductance of boost converter } \\
\text { (pv side) }\end{array}$ & $3.5 \mathrm{mH}$ & Balanced active and reactive load & $10 \mathrm{~kW}, 6 \mathrm{kVAR}$ \\
\hline $\begin{array}{l}\text { Filter coupling inductance } \\
\text { Controller gain }\end{array}$ & $\begin{array}{c}2.25 \mathrm{mH} \\
\mathrm{KP}=24, \mathrm{KI}=1.2\end{array}$ & $\begin{array}{l}\text { Unbalanced active and reactive } \\
\text { load }\end{array}$ & $\begin{array}{c}10 \mathrm{~kW}, 9 \mathrm{~kW} \text {, and } 11 \mathrm{~kW} \text {; } \\
6 \mathrm{kVAR}, 5.5 \mathrm{kVAR} \text {, and } \\
6.6 \mathrm{kVAR} \text {. }\end{array}$ \\
\hline
\end{tabular}

\section{ACKNOWLEDGEMENTS}

2021)".

This research work was supported by "Woosong University's Academic Research Funding - (2020-

\section{REFERENCES}

[1] S.M. Ismael, S. Aleem, A.Y. Abdelaziz, A.F. Zobaa, "State-of-the-art of hosting capacity in modern power systems with distributed generation," Renewable energy, vol. 130, pp. 1002-1020, 2019.

[2] A. Ehsan, Q. Yang, "Optimal integration and planning of renewable distributed generation in the power distribution networks: A review of analytical techniques," Applied Energy, vol. 210, pp. 44-59, 2018.

[3] S.E. Razavi, E. Rahimi, M.S. Javadi, A.E. Nezhad, M. Lotfi, M.S. khah, J.P.S. Catalão, "Impact of distributed generation on protection and voltage regulation of distribution systems: A review," Renewable and Sustainable Energy Reviews, vol. 105, pp. 157-167, 2019.

[4] K.H. Chao, S.H. Ho, M.H. Wang, "Modeling and fault diagnosis of a photovoltaic system," Electric Power Systems Research, vol. 78, pp. 97-105. 2008.

[5] T. Güney, "Renewable energy, non-renewable energy and sustainable development," International Journal of Sustainable Development \& World Ecology, vol. 26, no. 5, pp. 389-397, 2019.

[6] M. Ramli, H. Bouchekara, A.S. Alghamdi, "Optimal sizing of PV/wind/diesel hybrid microgrid system using multiobjective self-adaptive differential evolution algorithm,” Renewable energy, vol. 121, pp. 400-411, 2018.

[7] S. Hajiaghasi, A. Salemnia, M. Hamzeh, "Hybrid energy storage system for microgrids applications: A review," Journal of Energy Storage, vol. 21, pp. 543-570, 2019.

[8] H. Tian, L. Yunwei, "Virtual Resistor Based Second-Order Ripple Sharing Control for Distributed Bidirectional DC-DC Converters in Hybrid AC-DC Microgrid," IEEE Transactions on Power Electronics, pp. 1-1, 2020.

[9] S. Shrivastava, B. Subudhi, S. Das, "Distributed voltage and frequency synchronisation control scheme for islanded inverter-based microgrid," IET Smart Grid, vol. 1, no. 2, pp. 48-56, 2018.

[10] S. Tiwari, B. Singh, P.K. Goel, "Control of wind-diesel hybrid system with BESS for optimal operation," IEEE Transactions on Industry Applications, vol. 55, no. 2, pp. 1863-1872, 2018.

[11] M. Hassan, M. Chen, Q. Li, M. Mehmood, T. Cheng, B. Li, "Microgrid control and protection state of the art: a comprehensive overview," Journal of Electrical Systems, vol. 14, no. 2, pp. 148-164, 2018.

[12] O. Usta, "Microgrid Protection and Automations," In Microgrid Architectures, Control and Protection Methods, Springer, Cham, pp. 631-655, 2020.

[13] P.B. Nempu, N.S. Jayalakshmi, "A new power management strategy for PV-FC-based autonomous DC microgrid," Archives of Electrical Engineering, vol. 67, no. 4, pp. 815-828, 2018.

[14] A. Arani, G.B. Gharehpetian, M. Abedi, "Review on energy storage systems control methods in microgrids," International Journal of Electrical Power \& Energy Systems, vol. 107, pp. 745-757, 2019.

[15] M. Khan, J. Wang, M. Ma, L. Xiong, P. Li, F. Wu, "Optimal energy management and control aspects of distributed microgrid using multi-agent systems," Sustainable Cities and Society, vol. 44, pp. 855-870, 2019.

[16] M. Zia, E. Elbouchikhi, M. Benbouzid, "Microgrids energy management systems: A critical review on methods, solutions, and prospects," Applied energy, vol. 222, pp. 1033-1055, 2018.

[17] G. Talapur, H.M. Suryawanshi, L. Xu, "A reliable microgrid with seamless transition between grid connected and islanded mode for residential community with enhanced power quality," IEEE Transactions on Industry Applications, vol. 54, no. 5, pp. 5246-5255, 2018.

[18] P. Gong, Z. Lu, Z. Lv, "Local adaptive pinning synchronisation for distributed secondary control of islanded microgrid," IET Generation, Transmission \& Distribution, vol. 14, no. 8, pp. 1476-1482, 2020.

[19] U.K. Kalla, B. Singh, S.S. Murthyet, "Slide mode control of microgrid using small hydro driven single-phase SEIG integrated with solar PV array," IET Renewable Power Generation, vol. 11, no. 11, pp. 1464-1472, 2017.

[20] P. Shanthi, G. Uma, M.S. Keerthana, "Effective power transfer scheme for a grid connected hybrid wind/photovoltaic system," IET Renewable Power Generation, vol. 11, no. 7, pp. 1005-1017, 2017.

[21] M. Elsaharty, "Three-phase custom power active transformer for power flow control applications," IEEE Transactions on Power Electronics, vol. 34, no. 3, pp. 2206-2219, 2018.

[22] B.R. Madhu, M.N. Dinesh, T. Thinlas, D. Menezes, "Enhancement of power quality using microprocessor-based shunt active power filter for unbalanced load," International Journal of Electrical and Computer Engineering (IJECE), vol. 10, no. 4, pp. 3393-3402, 2020. 
[23] D. Danalakshmi, S. Bugata, J. Kohila, "A control strategy on power quality improvement in consumer side using custom power device," Indonesian Journal of Electrical Engineering and Computer Science, vol. 15, no. 1, pp. 80-87, 2019.

[24] A. Pawawoi, Zuheldi, F. Akbar, R. Nazir, "Analysis of energy losses reduction potential on the distribution line of campus building through electric power quality improvement," Indonesian Journal of Electrical Engineering and Computer Science, vol. 17, no. 2, pp. 868-876, 2020.

[25] S.A. Hussien, M.A. Deab, N.S. Hosny, "Improving the delivered power quality from WECS to the grid based onPMSG control model," International Journal of Electrical and Computer Engineering (IJECE), vol. 10, no. 6, pp. 6349-6360, 2020.

[26] Amirullah, O. Penangsang, A. Soeprijanto, "Matlab/simulink simulation of unified power quality conditionerbattery energy storage system supplied byPV-wind hybridusingfuzzy logic controller," International Journal of Electrical and Computer Engineering (IJECE), vol. 9, no. 3, pp. 1479-1495, 2019.

[27] G. Jayaraju, G.S. Rao, "Intelligent controller-based power quality improvement of microgridintegration of photovoltaic power system usingnew cascade multilevel inverter," International Journal of Electrical and Computer Engineering (IJECE), vol. 9, no. 3, pp. 1514-1523, 2019.

[28] P. Gakhar, M. Gupta, "A novel control strategy for power quality improvement in gridconnected solar photovoltaic system," Indonesian Journal of Electrical Engineering and Computer Science, vol. 15, no. 3, pp. 1264-1272, 2019.

[29] T.S. Gunawan, M.H. Anuar, M. Kartiwi, Z. Janin, "Design of power factor meter using internet of things for power factor improvement, remote monitoring and data logging," Indonesian Journal of Electrical Engineering and Computer Science, vol. 17, no. 2, pp. 700-709, 2020.

[30] J. Padulles, G.W. Ault, J.R.M. Donald, "An integrated SOFC plant dynamic model for power systems simulation," Journal of Power sources, vol. 86, no. 1-2, pp. 495-500, 2000.

[31] Y. Allahvirdizadeh, M. Mohamadian, M.R.H. Fam, "Study of energy control strategies for a standalone PV/FC/UC microgrid in a remote," International Journal of Renewable Energy Research (IJRER), vol. 7, no. 3, pp. 1495-1508, 2017.

[32] S.R. Das, P.K. Ray, A. Mohanty, "Fuzzy-Controller-Designed-PV-Based Custom Power Device for Power Quality Enhancement," IEEE Transactions on Energy Conversion, vol. 34, no. 1, pp. 405-414, 2019.

[33] G. Wu, K. Y. Lee, L. Sun, Y. Xue, "Coordinated fuzzy logic control strategy for hybrid PV array with fuel-cell and ultra-capacitor in a Microgrid,” IFAC-PapersOnLine, vol. 50, no. 1, pp. 5554-5559, 2017.

[34] A.N. Hussain, A.J. Ali, F.S. Ahmed, "Power quality improvement based on hybrid coordinated design of renewable energy sources for DC link channel DSTATCOM," International Journal of Electrical and Computer Engineering (IJECE), vol. 10, no. 5, pp. 5108-5122, 2020. 